\title{
調査報告
}

\section{長野県伊那市における昆虫食の実態と多様性 \\ Current Situation and Diversity of Entomophagy in Ina, Nagano Prefecture}

\author{
小林 直樹 \\ KOBAYASHI Naoki
}

\author{
(2020年 5 月 15 日受付 2020 年 9 月 25 日受理)
}

\begin{abstract}
本稿では，昆虫食習慣のある地域として長野県伊那市を取り上げ，地域の食文化とされる昆虫食について，食用 昆虫の採集および流通，消費実態を明らかにし，昆虫食の成立，継続する要件を考察した。アンケート調査の結 果, 当地域では現在でも多くの住民が昆虫を食べており，昆虫を地域の食材，食文化として認識していた。一方， 喫食頻度は低下傾向にあり，食用昆虫の流通構造などにも変化がみられる。伊那市の昆虫食は食用とされる昆虫の 種類ごとに異なる特徵をもっており，流通構造などの変化の仕方や変化度合いも昆虫ごとに違いがみられた．今後 当地域の昆虫食文化の存続を考えるためには，昆虫を食べない者の多い若い世代の増加による昆虫製品の需要の減 少や, 域外の原料に頼るかたちとなっている食用昆虫の流通の面に内在するリスクについて, さらに詳しい調査が 必要である。
\end{abstract}

The purpose of this study was to investigate the collection, distribution, and consumption trends of insects as food and attitudes toward entomophagy as a local food culture in the city of Ina, Nagano prefecture, Japan. According to the results of a questionnaire survey, more than $60 \%$ of respondents followed the custom of eating insects and some recognized insects as elements of local food and local food culture. However, there has been a decreasing trend in the frequency of insect consumption, and the environment surrounding entomophagy has been changing. At present, entomophagy in Ina and changes in consumption trends differ by type of insect in the area. Further investigations of decreases in consumption, especially among the younger generation, and of changes in distribution patterns when the resource supply is dependent on other regions are necessary when considering how to ensure that the custom of entomophagy is passed down to future generations in Ina.

キーワード：昆虫食，食文化，地域資源，自然資源，特産品

Key words: entomophagy, food culture, local resources, natural resources, special products

\section{I 研究の背景と目的}

昆虫の飼料および食料資源としての可能性に言及し た国連食糧農業機関の報告書 ${ }^{1)}$ が2013 年に発表されて 以降, 昆虫は新たな食資源として注目を集めている. 昆虫食をはじめ, 人間と昆虫との関わりに関する既存 研究は多数あり，野中（2005）はその整理として応用 昆虫学, 文化昆虫学, 民族昆虫学の三つの枠組みを提 示した.これまで, 野中の分類において応用昆虫学や 文化昆虫学に位置づけられる，昆虫の食品的側面や昆 虫食の文化事象的側面を明らかにする研究が積極的に おこなわれてきた（たとえば水野 2016; 三宅 1919; 三 橋 1997).

一方, 民族昆虫学は, 昆虫を食資源として利用して きた地域における人々の昆虫資源の利用実態や, 食資
源としての昆虫に人々がどのような認識をもってきた かに迫る視点をもつ．この視点に立つことで，地域の 食文化として昆虫食を成立, 継承させてきた地域にお ける食用昆虫の採集および流通，消費実態を明らかに することができる.

たとえば野中（1989）は，クロスズメバチ食慣行が みられる中部地方の複数地域においてその食用方法お よび入手方法を調査し，それぞれの地域差についてそ の背景にある各地の自然環境や流通環境の違い, 農作 業の変化などを指摘した。 その上で今後の研究課題と して, 食慣行の地域差を生み出す自然環境や流通環境 に関するより詳細な調查や，積極的な食慣行がみられ る地域の価值観の解明を挙げている．また藤岡（2006） は, ナミビアの農牧民の昆虫食について, 食用とされ る昆虫およびその入手, 調理方法と, それらの過去か 
ら現在にかけての変化を調査した。 その結果, 対象地 域の昆虫食は昆虫の生息環境や人々の生活様式の変 化，市場の形成などの影響を受けて，食用として利用 する昆虫の種類や入手方法に変化がみられることを明 らかにした。 ただし，こうした視点からの研究はいま だに少ない。

今後新たな食資源として昆虫の流通が拡大するなら ば，その大部分が養殖によってまかなわれることが予 想される，その一方で養殖技術が確立するまで，ある いは養殖技術確立後の「天然もの」として，採集され て供給される昆虫に対する需要が見込まれるとの指摘 もある（手代木 2019）。今後さまざまな地域で昆虫を 食資源として持続的に利用するためにも，民族昆虫学 的研究から得られる知見は重要であろう.

ここで昆虫食以外の地域の食文化に注目した地理学 的研究をみると，食資源の利活用の実態や分布，およ びその変容などについて注目してきたことがわかる. たとえば辻（1993）は，中国山地にみられるトチノミ 食について，採集慣行や加工に使う道具，加工工程や アク抜き技術に注目しながら中国山地の東部と西部で 地域差があることを指摘し, 両地域の過去の食料事情 の違いやトチノミ食とほかの食習俗の関係について考 察した。 また升原（2005）は，地理学が郷土料理を扱 う際に，食材の採取や食用方法だけでなく流通を含め た地域的分析の重要性を指摘した。 その上で広島県に おけるサメ食について食材の採取地や流通経路，家庭 での食実態の変化を明らかにした。中村（2017）は, 宮崎県の伝統的魚介類食に関して調査し，一口に魚介 類食ととらえられてきた食文化を細かく分類し，それ ぞれの魚介類食の地理的分布の特徵やその要因を詳細 に分析した.

これらの研究は，それぞれの食文化の実態だけでな く，その成立や継承に関わる人々の情報や，一つの食 文化内部にみられる文化的な多様性を明らかにした。 それは，地域社会が食資源を維持，活用するために 培ってきた知恵の発見，あるいは資源量の減少や流通 構造の変容などに対応しきれず，食習慣の維持や継承 が困難になった事例の確認に繋がった．現代の食資源 利用がさまざまな事情を背景に成り立っていることを 理解するきっかけを与えてくれた研究である.

現在の日本では昆虫を食べる習慣は一部地域にのみ
残っており，その地域の伝統食や郷土料理として扱わ れている（田下ほか 2015）。そのため昆虫食は，その 習慣のないほかの多くの地域の視点から，それ自体が 特徴的な文化としてとらえられてきた。昆虫食という 大きなくくりで認識されてきたために，その内部に存 在するであろう文化的な多様性には目が向けられにく かったと考えられる．日本では過去には数十種類，現 在でも数種類から十数種類の昆虫が食用とされている (野中 2008)。これらは生息環境がそれぞれ異なり， 人間が採集する際の採集環境や採集方法，さらには加 工，流通経路も異なっていると考えられる．他の食文 化に関する地理学的な研究同様, 昆虫食についてもこ れらの点に関して詳細な研究をおこなう必要性が指摘 される。

以上を踏まえて本稿では，特定の地域において現在 食用とされている複数の昆虫を対象に，それぞれの採 集や流通，消費状況，さらに生息環境や採集環境の特 徵とその変化を明らかにすることを目的とする。この 目的に対して本稿では, 複数種類の食用昆虫に関して 一貫した項目を設定して実施した調査の結果を基に， 採集や流通，消費に関する昆虫同士の比較に基づく考 察を可能とする。これは，昆虫食の成立条件につい て，現在ひとくくりに昆虫食と認識されているこの食 文化が, 昆虫ごとに異なる特徴をもつ食文化の重なり 合いにより成立しているという，昆虫食内部の文化的 な多様性を解明することに慗がる。そしてそこから得 られた知見は，今後昆虫資源利用の維持，継承を考え る際に参照できる有用な情報にもなると考えられる． 本稿でも最後に今後の昆虫資源利用の動向や持続可能 性について考察する.

\section{II 調査対象地域および調査方法}

\section{1. 調查対象地域}

本稿では調査対象地域および事象として長野県伊那 市の昆虫食を選定した。伊那市は，2006年に伊那市， 高遠町，長谷村が合併し新設された市である（図 1). 伊那市における昆虫食の記録は，市史をはじめ書籍な どに数多くみられ（たとえば，伊那市 1981; 手良誌編 集委員会 2012)，この地域で現在に至るまで食べ続け られている主な昆虫として，イナゴ，八チの子，ザザ 
ムシ，カイコ(サナギ）の4種類が挙げられている. そのうちイナゴ, 八チの子, ザザムシの 3 種類は, 「三大珍味」として市の特産物とされている，市内直 売所では年間を通じて土産品として売られるほか, 量 販店などでも季節になると生鮮食品として並ぶなど, それらを食すことは地域を代表する食文化となってい

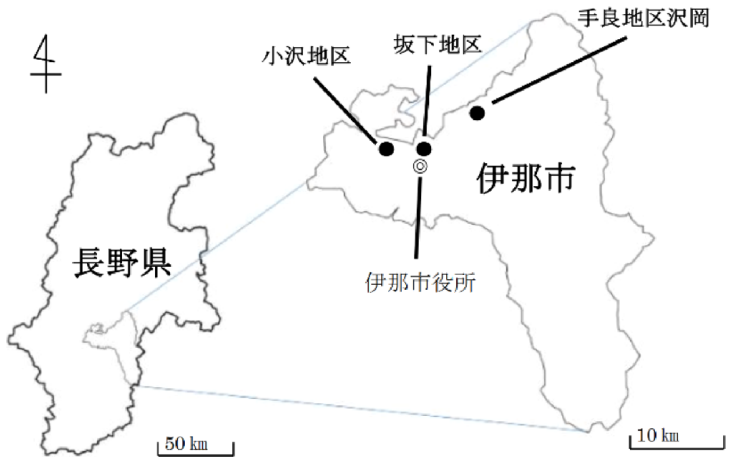

図 1 調査対象地域

Fig. 1 Study area
る.そこで本稿においてもこの3 種類にカイコのサナ ギを加えた 4 種類の昆虫食を考察対象にした.

2. 対象とする食用昆虫の概要

イナゴは調査対象地域のみならず，日本における昆 虫食の対象として代表的な昆虫である（田下ほか 2015）， イナゴ覀科 Oxyinaeに属する数種類のバッタの仲間を 指す総称であり，食用とされるものの多くはコバネイ ナゴOxya yezoensis（図2-a）やハネナガイナゴOxya japonicaである. かつての伊那市の風習をまとめた文 献には，「秋の遊び」として「イナゴ捕り」が挙げられ ている（手良誌編集委員会 2012）ほか，9月の行事と して「イナゴ捕り」が紹介されている（伊那市 1999）. 現在でも秋になると市内の販売店で調理済みのイナゴ がトレーに入れられ販売されており，日常食としての 色も強い.

ハチの子は, 主にクロスズメバチVespula flaviceps （図2-b）やシダクロスズメバチVespula shidaiなどの幼

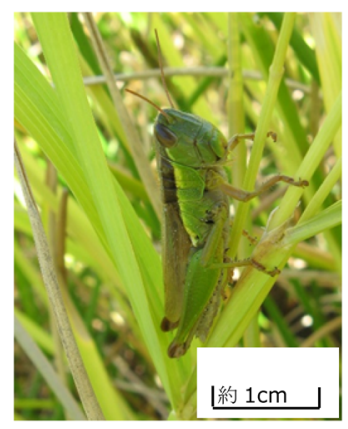

a. コバネイナゴ Oxya yezoensis

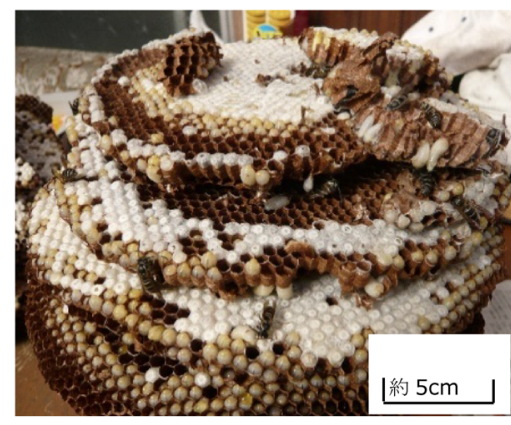

b. クロスズメバチとその巣 Vespula flaviceps and its nest

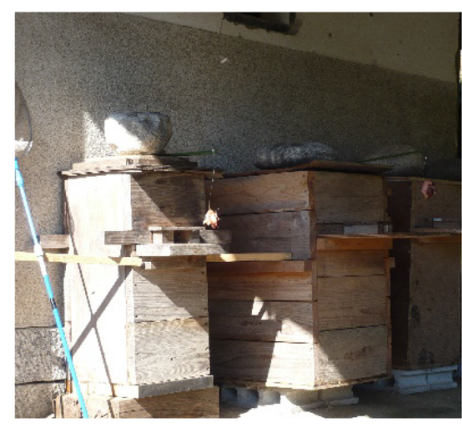

c. クロスズメバチの飼育の様子 rearing Vespula

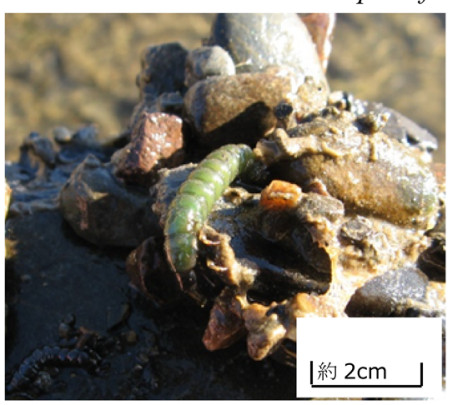

d. トビケラの仲間の幼虫 larva of Trichoptera

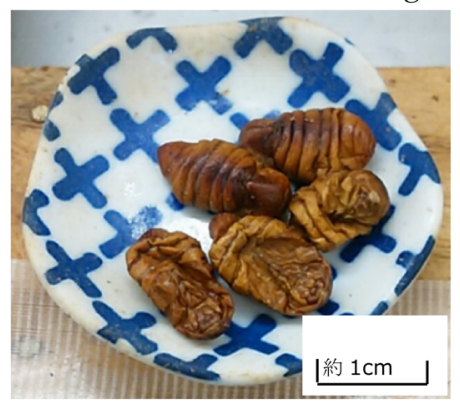

e. カイコのサナギ pupas of Bonbyx mori

図2 伊那市で食用とされている昆虫

Fig. 2 Edible insects in Ina

（aは2018年 10 月，伊那市で撮影，bは2018年11月，岐皁県恵那市で撮影，cは2019年 11 月，岐皁県恵那市で撮影， d は2019年 1 月，伊那市で撮影， eは2019年3月，長野県岡谷市で撮影) 
虫およびサナギそのものと，それらを調理したものを 指す。このハチは「地蜂」や「へボ」など地域ごとに さまざまな呼び方がされており，調査対象地域では 「スガレ」と呼称されている，八チの子食は「趣味」 や「遊び」としての色が強い文化であり, 調査対象地 域をはじめハチの子を食する地域ではクロスズメバチ のライフサイクル（野中 2005）を利用し，巣の採集や 飼育をおこなっている。初夏に作られ始めたばかりの 巣を持ち帰り，秋まで家の庭などで飼育する（図2-c） ほか，巣を見つける過程そのものも「ハチ追い」など と呼び人々の遊びの一環となっている. 調査対象地域 でも「スガレ追い」が秋の行事として挙げられている (伊那市 1999).

ザザムジ2)は，主にトビケラ Trichoptera（図2-d), カワゲラ Plecoptera, ヘビトンボMegalopteraの仲間の 幼虫の総称である（牧田 1999）。全国に生息しており， いずれも成虫になるまでの 1 年から数年間を水中で過 ごす．川の環境変化の影響を強く受ける昆虫であり， 水質を判断する際の「きれいな水」の指標生物とされ ている（伊那市・川シンポジウム実行委員会 1996）. また，その生育は水質以外にも川底の環境や水量の影 響も受ける（太田・高橋 2001）。ザザムシは調査対象 地域を含む伊那谷地域を代表する昆虫食である（長野 県 2019)．かつては長野県内のほかの地域でもザザム シを食べる文化があったが，現在この文化が残るのは 調査対象地域のみといわれ（牧田 1999），ザザムシを 捕る文化もこの地域のみに残存する。漁は冬季にのみ おこなわれることから, 調査対象地域の冬の風物詩と しても報道される ${ }^{3)}$.

カイコBombyx moriはそのサナギ（図2-e）が食用と されてきた。この食文化は，カイコのサナギが養蚕農 家や製糸工場から大量に排出されるものであったこと から，養虫業の衰勢との関連が強い，養蚕が盛んな地 域では食用以外にも養殖鯉の慨などとして利用されて きた（Nakanishi 2009）。調査対象地域では1950年代 頃まで大部分の農家でカイコを飼育していた（伊那市 1981）が，その後養虫業は衰退し，現在伊那市で養蚕 をおこなっている家はない（IVの4.で詳述）。しかし， 養蚕がおこなわれている近隣地域で手に入るサナギを 加工した製品が直売所などで販売されている.

\section{3. 調査の実施概要}

調査は伊那市民を対象に昆虫の入手方法や消費につ いてのアンケート調査, また, 市内に存在する昆虫食 に関係する個人や団体，事業者への聞取りを軸におこ なった。

アンケート調査では, 伊那市の手良地区沢岡, 坂下 地区，小沢地区を対象地区に設定した，各地区の世帯 数は, 手良地区沢岡が 260 , 坂下地区が 434 , 小沢地 区が254である（合計948世帯）。地区の選定において は, 中心市街地とその周辺部, 市街地から離れた郊外 の農村部を含め, 幅広い年代や職業層の回答を得るこ とができるよう考慮した。調査票の配布には，郵便局 のタウンプラスを利用し，2019年9月半ばに対象地区 の各世帯に 1 部ずつ配布した。回答後の調査票は，料 金後納郵便により，配布後から 10 月末までの期間を 定め, 回収した。

アンケートでは，昆虫食の経験の有無や，昆虫を食 べる機会の増減とその理由, 現在と過去の入手方法と 消費の実態を中心に調查した，特に入手方法について は，生きた昆虫を回答者自身が採集するのか，調理済 みのものを店で購入するのかなどを詳しく把握できる よう細かく設問した。

回収数/配布数は $357 / 948$ であり，回収率は $37.7 \%$ で あった。アンケート結果の集計は3地区をまとめてお こなった，回答者の基本属性として年齢別の割合を図 3 に示した. 20 歳代と 30 歳代は回答数が少ないため, 統合して一つの集計単位とした。60歳代からの回答が $27.2 \%$ と最も多く，次いで多かった 70 歳代を合わせる と全体の半数以上がこの年代からの回答となった。調 査票を各家庭 1 部ずつ配布したため年長者が回答する

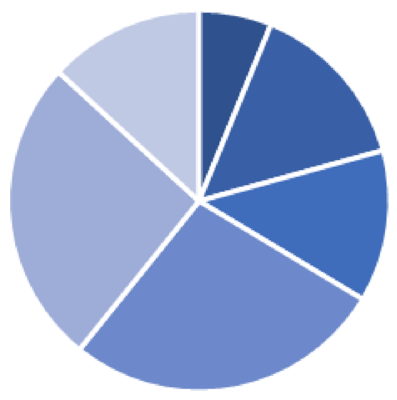

- $20 \cdot 30$ 歳代

- 40 歳代

- 50 歳代

-60歳代

- 70 歳代

- 80 歳代以上

図3 回答者の年代別割合

Fig. 3 Distribution of survey respondents by generation (アンケート結果より作成) 
傾向にあったことや，調查対象地域の高齢化 ${ }^{4)}$ が影響 した結果と考えられる。このため, 本調查結果では若 年層の昆虫食に対する意識や喫食状況はほかの年代の それと比べて正確性を欠いた把握となってしまう。 そ こで考察では世代構成に配虑し，またほかの年代の回 答者による若年層の喫食状況に関する記述等も参考に する。これにより今回取得したデー夕から調查対象地 域の昆虫食の実態をおおお方去把握することは可能と判 断した.

聞取り調查では，伊那市内で昆虫製品の製造，販売 を抢こなっている直売所 $\mathrm{A}$ と販売店 $\mathrm{B}$ を対象に，店で 扱う製品に使用している原料昆虫の仕入れ先や仕入れ 価格とそれらの変化について質問した。また，八チの 子食の継承を目指した活動を展開している伊那市地蜂 愛好会と全国地蜂連合会を対象に, 団体の来歴や具体 的な活動内容について質問した，さらに，天竜川漁業 協同組合に対して，ザザムシ漁師の数やザザムシの漁 獲量推移について質問した。

\section{III 伊那市における昆虫食の実態 一アンケート調査結果一}

1. 昆虫食の経験, 食習慣の有無, 喫食頻度の変化 およびその理由

住民にこれまでに昆虫を食べた経験があるかを問う た。結果，回答者 357 人中 344 人 $(96.4 \%)$ が昆虫を 「食べたことがある」と回答した．年代別にみても全て の年代で 8 割以上の回答者が昆虫食の経験があると回 答しており, 調查対象地域では $20 \cdot 30$ 歳代以上の住民 の大半が昆虫を食べたことがあるということがわかる.

ただし，この設問からでは何かの機会に一度だけ昆 虫を食べたことがあるのか，ある程度習慣的に昆虫を 食べているのかということはわからない，そこで「食 べたことがある」と回答した 344 名を対象に，過去 2 年 程度を目安に現在昆虫を食べているかを問うた，その 回答状況を年代別に図4に示した。結果，昆虫食の経 験がある住民で現在昆虫を食べていると回答した者の 割合は $66.6 \%$ であり，その内訳をみると， $20 \cdot 30$ 歳代 や 40 歳代といった比較的若い世代の住民の半数以上 は現在昆虫を食べていないことがわかる．年代が上が るにつれ食べていると回答した住民の割合は増加する

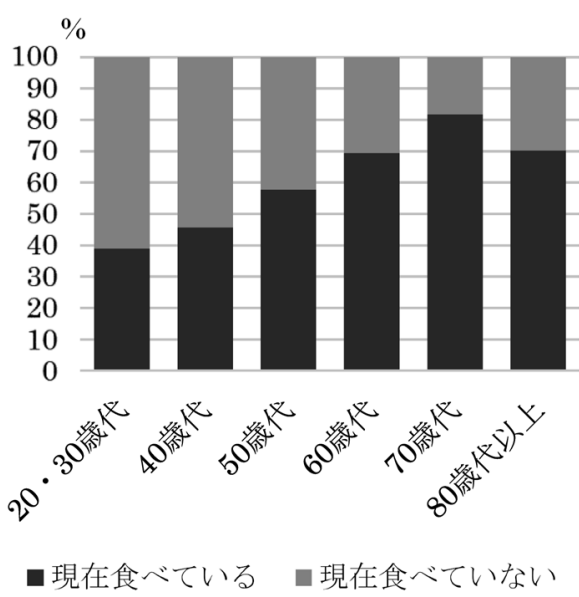

図4 昆虫を食べる習慣の有無

Fig. 4 Survey respondents following/not following the custom of entomophagy

注：各年代の回答者数は, $20 \cdot 30$ 歳代：18名, 40 歳代：46 名，50歳代：45名，60歳代：95名，70歳代：93名，80 歳代以上：47名

$$
\text { （アンケート結果より作成） }
$$

傾向がみてとれ，60歳代と 80 歳代以上の 7 割近く, 70 歳代の 8 割以上が現在も昆虫を食べていると回答し た。なお，アンケート回答者全体のうち現在昆虫を食

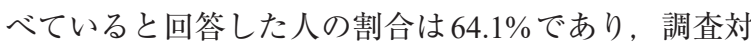
象地域では現在でも半数以上の住民が昆虫を食べてい ると考えられる。

続いて，現在昆虫を食べていると回答した住民に $\lceil 20$ 年ほど前と比べた喫食頻度の変化」を問うた。な お，この設問への回答の集計は30歳代以上からの回 答のみを対象としておこなった。結果，9割以上の住 民が「減った」と回答した。「変わらない (維持)」が $8.1 \%$,「増えた」は $0.9 \%$ とわずかであった。

喫食頻度の変化, 維持の理由や背景を選択式（複数 回答可）で問うた設問に対する回答状況を表 1 に示し た。なおここでは昆虫食の経験の有無を問うた先の 設問で「食べたことがない」と回答した住民に対して その理由を問うた結果もともに示した。

喫食頻度が「増加」したと回答した住民は極端に少 ないため設問への回答状況のみではその理由や背景を 指摘することは難しい，ただし，おいしさや季節性， 昔からの馴染みや地域の食材であるという認識など, 頻度「増加」と「維持」との回答内容に重なるものが 多い。よって，こうした要素が昆虫を食べる頻度の維 持もしくは増加に寄与していると考えられる。なお 
表 1 梁食頻度の変化の理由

Table 1 Reasons for changes in the frequency (increase or decrease) or maintenance of insect consumption

\begin{tabular}{|c|c|c|}
\hline $\begin{array}{c}\text { この } 20 \text { 年間での喫食頻度の変化 } \\
\text { (回答者数) }\end{array}$ & $\begin{array}{c}\text { 増加・減少・維持, 食べたことがない理由や背景 } \\
\text { (複数回答) }\end{array}$ & $(\%)$ \\
\hline 増加（3） & $\begin{array}{l}\text { おいしいから } \\
\text { 季節の食材だから } \\
\text { 地域の食材だから } \\
\text { 知人がくれるから } \\
\text { 昔から慣れ親しんでいるから }\end{array}$ & $\begin{array}{r}100.0 \\
66.7 \\
66.7 \\
66.7 \\
33.3\end{array}$ \\
\hline 減少（307） & $\begin{array}{l}\text { 食べる機会がないから } \\
\text { 身近な場所で昆虫がとれなくなったから } \\
\text { 値段が高いから } \\
\text { 知人等のくれる人がいなくなったから } \\
\text { 山や畑に行かなくなったから } \\
\text { 見た目が嫌だから } \\
\text { 肉や魚を食べればよいから } \\
\text { 家族がきらいだから } \\
\text { 昔から食べる機会が少なかったから } \\
\text { 調理に手間がかかるから } \\
\text { 食事の他のメニューと合わないから } \\
\text { 調理方法が分からないから } \\
\text { 味が苦手だから }\end{array}$ & $\begin{array}{r}40.4 \\
35.2 \\
28.0 \\
16.0 \\
15.6 \\
15.5 \\
12.7 \\
8.5 \\
7.8 \\
4.9 \\
2.9 \\
2.3 \\
1.6\end{array}$ \\
\hline 維持（28） & $\begin{array}{l}\text { 昔から慣れ親しんでいるから } \\
\text { おいしいから } \\
\text { 地域の食材だから } \\
\text { 季節の食材だらら } \\
\text { スーパー等で調理済みのものが売られるようになったから } \\
\text { 知人がくれるから } \\
\text { 家族が好きだから } \\
\text { 値段が手頃だから } \\
\text { 食べる機会がないから } \\
\text { 見た目が嫌だから } \\
\text { 肉や魚を食べればよいから } \\
\text { 値段が高いから } \\
\text { 知人等のくれる人がいなくなったから } \\
\text { 食事の他のメニューと合わないから } \\
\text { 調理方法が分からないから } \\
\text { 家族がきらいだから }\end{array}$ & $\begin{array}{r}57.1 \\
53.6 \\
53.6 \\
39.3 \\
35.7 \\
21.4 \\
17.9 \\
14.3 \\
14.3 \\
14.3 \\
14.3 \\
10.7 \\
3.6 \\
3.6 \\
3.6 \\
3.6\end{array}$ \\
\hline 食べたことがない（13） & $\begin{array}{l}\text { 見た目が嫌だから } \\
\text { 食べる習慣がないから } \\
\text { 昆虫そのものがきらいだから } \\
\text { 味が悪そうだから } \\
\text { 食べる機会がないから } \\
\text { 肉や魚を食べればよいから } \\
\text { 値段が高いから } \\
\text { 調理方法がわからないから }\end{array}$ & $\begin{array}{r}77.0 \\
61.5 \\
38.5 \\
30.8 \\
23.1 \\
15.4 \\
7.7 \\
7.7\end{array}$ \\
\hline
\end{tabular}

(アンケート結果より作成)

「維持」の理由では $21.4 \%$ が「知人がくれるから」(6 位)，17.9\%が「家族が好きだから」（7位）と上位 5 位 に続いてみられた回答であり，おすそ分けの習慣や家 族の好みも契食頻度に影響している様子がみられる。

頻度「減少」の理由として, 契食機会がないことや 住民自身での昆虫採集の困難性，販売されている製品
の価格などが挙げられた。なお， $12.7 \%$ が回答した 「肉や魚を食べればよいから」（7位）や1.6\%が回答し た「味が苦手だから」（13位）といった項目も選択肢 に用意していたが, 上位の理由に比べ回答者は少な かった。

これらの結果から, 食べる頻度の減少は住民の昆虫 
の味に対する不満や，たんぱく質の摂取を昆虫からす る必要がなくなったことが原因ではないことがわか る。むしろ味の良さや地域の食材として昆虫を評価し ている住民は多いが，身近な場所で食用とする昆虫を 手に入れることができなくなったことや，販売店での 販売状況が，契食頻度の減少に影響していることがう かがえる。

\section{2. 食用とされている昆虫とその変化}

表 2 は，昆虫食の経験があると答えた回答者 344 名に 対しこれまでに食べたことのある昆虫の種類，および 現在昆虫を食べていると答えた回答者229名に対し食 べている昆虫の種類を尋ねた結果を示している，なお， イナゴ，ハチの子，ザザムシについては選択式とし， そのほかの昆虫については自由記述として回答を得た。

これによるとイナゴ，八チの子を食べたことがある と答えた者が圧倒的に多いことがわかり，昆虫食の経 験がある住民の9割前後はこの2種類の昆虫を食べた ことがあると回答した，次いでザザムシ，カイコのサ ナギが多いという結果となった．加えて，上述の4種 類に比べ少数ではあるが, このほかに複数種類の昆虫 が食されていたことがわかる。

次に現在も食用とされている昆虫をみてみると， 「食べたことのある昆虫」で回答者の多かった 4 種類 の昆虫のみが挙げられ, それ以外の昆虫は現在食べら れていないことがわかる。また，4種類のうちカイコ のサナギについては現在食べていると回答した者の数 はほかの3種類の昆虫に比べ少なかった。

\section{3. イナゴの消費実態とイナゴ食に関する経験}

図 5 は，先の設問で現在昆虫を食べていると回答し た住民に対して，どのようにイナゴを入手しているの かを尋ねた結果を示したものである。この設問では 「昔 $(20$ 年ほど前 $) 」$ と「現在」の入手方法を選択式 (複数回答可) で尋ねた.

これをみると，昔は「自分や家族で捕まえた」とい う回答が最も多く，7割近い住民がこれを選択してい る. 続いて「友人等からもらった」という回答が多く, この二つが入手方法の 8 割前後を占めていたことがわ かる．続いて現在の入手方法に注目すると，「自分や 家族で捕まえた」という回答が大きく減少し，「調理
表 2 食用昆虫の種類

Table 2 Species of insects consumed as food

\begin{tabular}{lcc}
\hline \multicolumn{1}{c}{ 昆虫 } & $\begin{array}{c}\text { 食べたことがある } \\
\text { (回答者数) }\end{array}$ & $\begin{array}{c}\text { 現在食べている } \\
\text { (回答者数) }\end{array}$ \\
\hline イナゴ & 331 & 198 \\
ハチの子 & 315 & 179 \\
ザザムシ & 205 & 82 \\
カイコのサナギ & 94 & 12 \\
カミキリムシの幼虫 & 11 & 0 \\
カマキリ & 10 & 0 \\
ゲンゴロウ & 9 & 0 \\
コオロギ & 7 & 0 \\
セミ & 7 & 0 \\
キリギリス & 6 & 0 \\
その他のハチ & 4 & 0 \\
アリ & 2 & 0 \\
\hline
\end{tabular}

(アンケート結果より作成)

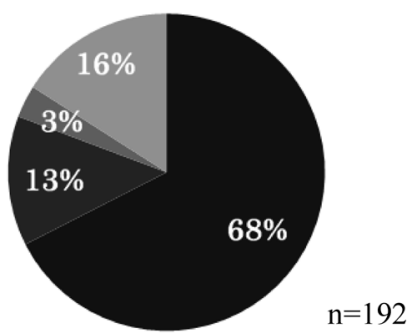

a. 20 年ほど前

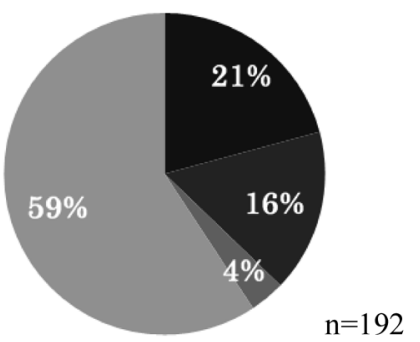

b. 現在

ロ 自分や家族で捕まえる

友人等からもらう

ロ生きたものを店で購入する

調理されたものを店で購入する

図 5 イナゴの入手方法

Fig. 5 Methods for obtaining Oxyinae (grasshoppers) (アンケート結果より作成)

されたものを店で購入する」が最も多くの回答を集め た.自由記述闌にも「昔は自分で捕まえたが，今は店 で買う」（70歳代男性）といった記述が多くみられた。

調理済みのものを買うと答えた回答者にどこで購入 しているかを記述式で尋ねた設問（複数回答可）には 
134 名が回答した。結果, $63.4 \%$ が回答した「市内の スーパー」と， $61.2 \%$ が回答した「直売所」の二つが 購入先の大半を占めた。 そのほかに回答のあった「土 産店」は回答率が $5.2 \%$ とわずかだった。

また，事前調査における市内の直売所での聞取りか ら, 調査対象地域では昆虫が捕れる時期になると市内 の直売所などで食用向けの昆虫が生きたまま販売され るという話を聞き「生きたものを店で購入」という選 択肢を設けたが，これを選択した回答者は過去現在に かかわらず少なかった。

なお，この設問では上述の通り「昔」を「20年ほど 前」と設定したが，自由記述の中に「20年前は稲刈りで 既にコンバインを利用しており，イナゴを捕ることも あまりなかった」(50歳代男性)，「イナゴ等を捕まえて いたのは 50〜 60年前. 20 年前は現在のように買って いた」（70歳代男性）といった記述が一定数みられた.

これらの記述をまとめると, 住民が自ら食用昆虫を 捕まえていた時期として 40 〜 60 年前が多く挙げられ ていた。「20年ほど前は田んぼによくイナゴがいた」 （50歳代女性）という記述もみられたものの, 年齢の 高い回答者ほどより古い時代を指摘している傾向もみ てとれた。これらは各人の記憶に依存した回答で正確 さに限界があり，こうした世代による年代認識のずれ が生じていると考えられる。 よって今回のアンケート の知見からのみではこうした年代の特定はできないた め, この点の検証は今後の研究課題とする.

表3はアンケートでイナゴの採集や調理，消費等の 経験に関する思い出や現在の様子について自由記述で 回答を求めた設問への回答で特徵的な内容を示したも のである。これにより，農家が稲刈りの時期にイナゴ を捕まえ，家庭で食べるということが多かった様子が うかがえるほか，学校や保育園で季節の行事や食育の 題材などとしても使われていたことがわかる。一方, 農業の手法や人々の就業形態の変化，あるいは高齢化 によって住民がイナゴを捕る機会が昔に比べ減少して いることもわかった

4. 八チの子の消費実態と八チの子食に関する経験 図6は，先の設問で現在昆虫を食べていると回答し た者に対して，八チの子の入手方法の変化について尋 ねた結果を示したものである。昔は「自分や家族で捕
まえた」という回答が最も多く、「友人等からもらっ た」という回答が続いた．現在の入手方法に注目する と，「自分や家族で捕まえた」という回答が大きく減 少した一方，「調理されたものを店で購入する」が増 加し, 最も多くの回答を集めた。 この変化の傾向はイ ナゴと同様である一方，八チの子は昔から「友人等か らもらった」という回答が3割以上あり，現在でもこ の入手方法を回答した者の割合が減少していないとい う点でイナゴとは異なっている.

表4 はアンケートでハチの子の採集や調理，消費等 の経験に関する思い出や現在の様子について自由記述 で回答を求めた設問への回答で特徵的な内容を示した ものである.IIの2.より, 調査対象地域ではクロスズ メバチの採集や飼育が季節の行事として文献に取り上 げられているが，自由記述からも巣を見つける過程や 見つけた巣の飼育に楽しみを見出している者が複数確 認できる，中には食べること以上に捕ることに魅力を 感じている者がいることもうかがえる，巣を見つける 「スガレ追い」や巣の飼育には高度な技術が必要であ り，新たにこれを始めようとする者の障壁になること が考えられる一方，技術の習得や習熟の楽しさや難し さが人々を惹きつけているという面もある。

5. ザザムシの消費実態とザザムシ食に関する経験 図7は,ザザムシの入手方法の変化について尋ねた 結果を示したものである.イナゴとハチの子とは異な り，昔，現在ともに入手方法として「調理されたもの を店で購入した（する）」に最も多くの回答が集まっ た．現在の入手方法としてこの回答の割合が最も高い 点はほかの昆虫と同様だが，「自分や家族で捕まえる」 と回答した者の割合はほかの昆虫と比べ極端に低かっ た. 自らザザムシ漁をする者が減少したことはIVの 3. で示す鑑札購入者数の推移とも一致する. これは, ザザムシ漁には技術が求められることや，漁に鑑札が 必要であることなどが関係していると考えられる.

表 5 はアンケートでザザムシの漁や調理，消費等の 経験に関する思い出や現在の様子について自由記述で 回答を求めた設問への回答で特徵的な内容を示したも のである. 自由記述からも，購入もしくは拉すそ分け でザザムシを入手する者が多いことがわかる。また， 販売されているものは高価でありなかなか買うことが 
表3 イナゴ食に関する自由記述の例

Table 3 Examples of free comments on Oxyinae consumption

\begin{tabular}{|c|c|}
\hline 確認された項目・観点 (回答数) & 記入の事例（回答者の年代・性別） \\
\hline 「イナゴ捕り」の経験（111） & 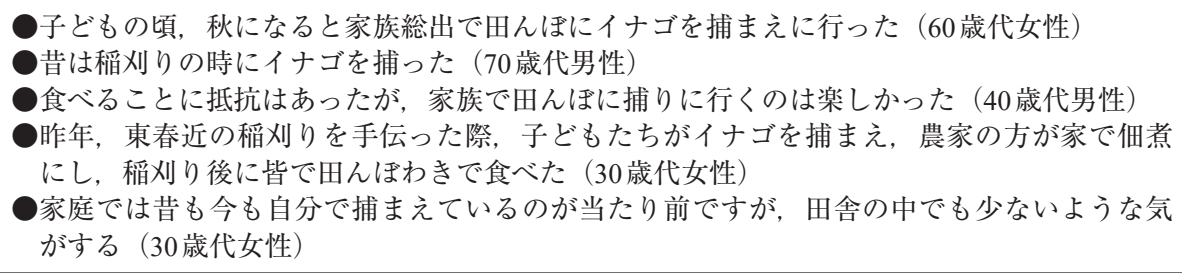 \\
\hline $\begin{array}{l}\text { 採集機会の減少と } \\
\text { 購入頻度の増加 (49) }\end{array}$ & 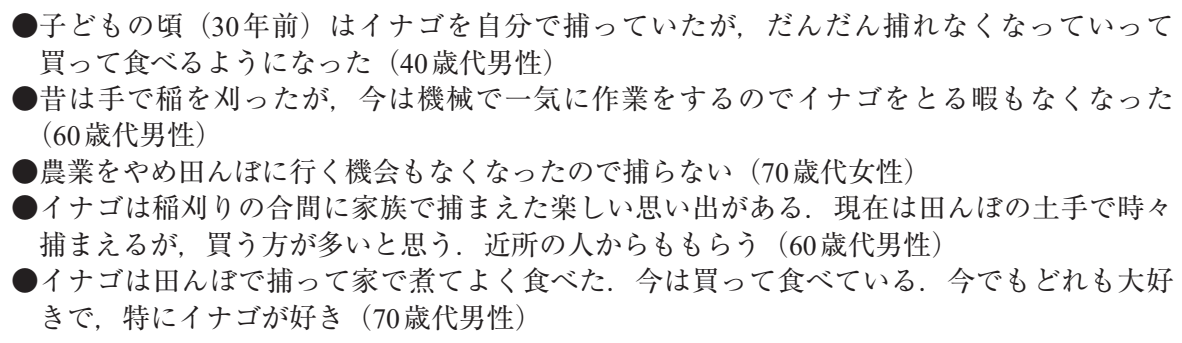 \\
\hline 日常食としての扱い（36） & 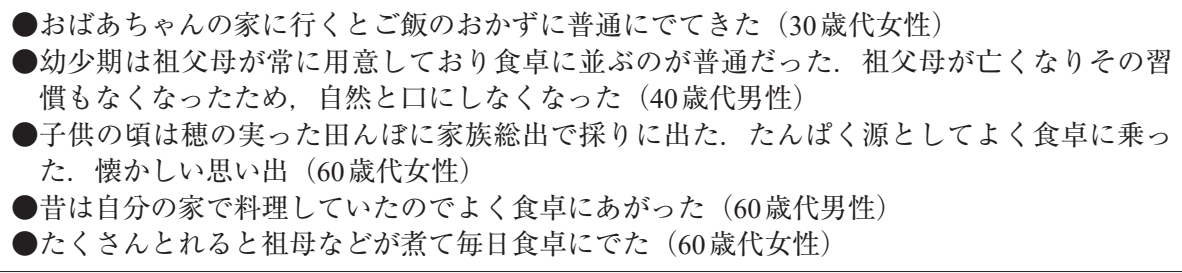 \\
\hline 農地のイナゴの減少（29） & 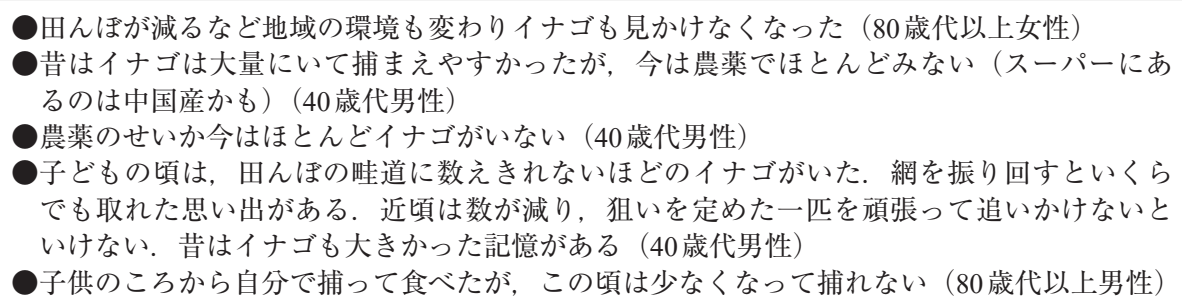 \\
\hline $\begin{array}{l}\text { 学校, 保育園での } \\
\text { 季節の行事や食育の題材, } \\
\text { 給食の献立としての扱い }(10)\end{array}$ & 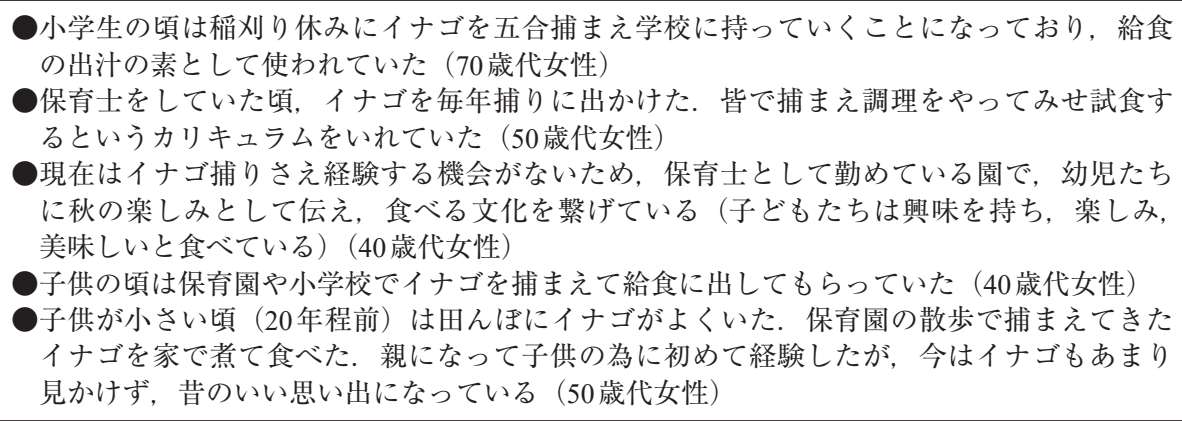 \\
\hline イナゴ製品の価格（9） & 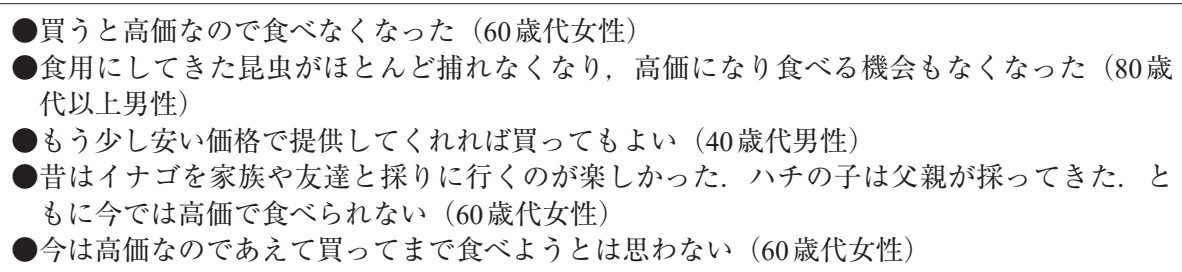 \\
\hline
\end{tabular}

注：「記入の事例」は語句や数值の表記形態を統一した上で, 原文の表現のまま使用.

（アンケート結果より作成） 


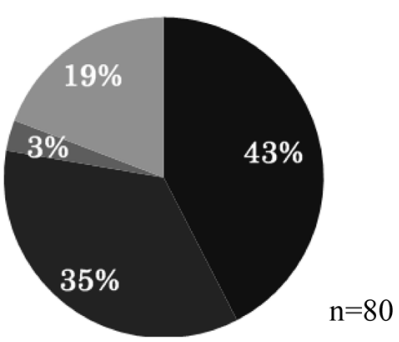

a. 20 年ほど前

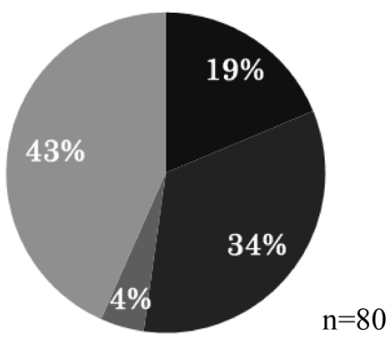

b. 現在

、自分や家族で捕まえる

友人等からもらう

ロ生きたものを店で購入する

啁理されたものを店で購入する

図6 八チの子の入手方法

Fig. 6 Methods for obtaining hachinoko (yellowjacket larvae/pupae)

(アンケート結果より作成)

できないという記述もあり，これもIVの3.で示すほ かの昆虫の価格との比較と一致する.

6. カイコのサナギの消費実態とカイコのサナギ食 に関する経験

アンケート結果からカイコのサナギは現在でも調査 対象地域で食べられている昆虫である一方, 過去, 現 在ともにほかの3 種類の昆虫に比べ食用とする人は少 ないといえる。

調査対象地域で食用とされるカイコのサナギは, カ イコの網から商品となる生系を取り出した後に残る産 業廃棄物であり，養虫が盛んだった頃は製糸工場から 大量に排出された。その利用方法の一つが食料として の利用である。アンケートの自由記述闌には「戦時中 食べ物の少ない頃食べた」(80歳代男性),「生糸につ んだ後のサナギを乾煎りして佃煮で食べた」（80歳代 女性)，「昔は農家ではカイコを飼っていたのでサナギ はよく食べて，今でも買って食べている」（70歳代女
性）といった記述があり，家庭でサナギを調理，消費 していたことや，「製糸工場で仕事をしているときに つまみ食いした」（80歳代女性）など, 製糸工場で取 り出されたサナギも消費していたことがうかがえる. かつては養虫農家や製糸工場で消費がみられた一方， 「今は買って食べる」（70歳代男性）といったアンケー トの記述が複数みられる. IVの4.で示す通り調查対象 地域内に養蚕農家がなくなった現在では販売されてい るものを購入して食べていることがこうした記述から 読み取れる。

なお，カイコのサナギは「においがあって食べられ なかった」(60歳代男性)，「栄養があると言われ食べ させられたが，油臭くて子どもながらにも苦手だっ た」（60歳代女性）など，ほかの3 種類の昆虫に比べ 「美味しくない」という意見が多かった。

\section{IV 伊那市における食用昆虫の 流通構造と資源維持・活用方法}

1. イナゴ

1）流通構造と特徵

アンケート結果より調査対象地域で現在イナゴを食 べる住民の多くは「調理されたものを店で購入する」 と答えていることから，販売店の原料供給先を調べる ことで, 原料供給面でどういった地域に依存している のかを明らかにできる.

伊那市内の直売所 $\mathrm{A}$ では 25 年前の創業当時から昆 虫製品を製造，販売している．初期は原料として伊那 市や近隣の地域のイナゴを使っていたものの，次第に 手に入りにくくなった，加えて需要量も多く，原料を 確保する必要があったため, 20 年程前より主に中国か らイナゴを輸入し原料として利用している。

また，同じく自社で昆虫製品の製造，販売をおこ なっている市内の販売店 $\mathrm{B}$ は, 東北地方や新潟県と いった長野県外から仕入れたイナゴを利用している.

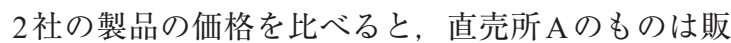
売店 Bより $100 \mathrm{~g}$ 当たり $100 \sim 200$ 円程安く販売され ていた。原料の仕入れ先により価格に違いが生じてい ると考えられ，国内より海外の原料の方が安いといえ る。また, 調査対象地域ではこの 2 社以外の量販店で もイナゴ製品が販売されており，それらは販売店 Bで 
表4 ハチの子食に関する自由記述の例

Table 4 Examples of free comments on hachinoko consumption

\begin{tabular}{|c|c|}
\hline 確認された項目・観点（回答数） & 記入の事例（回答者の年代・性別） \\
\hline $\begin{array}{l}\text { 家族が捕ってきた, } \\
\text { 知人等からおすそ分けされた経験 } \\
\text { (41) }\end{array}$ & 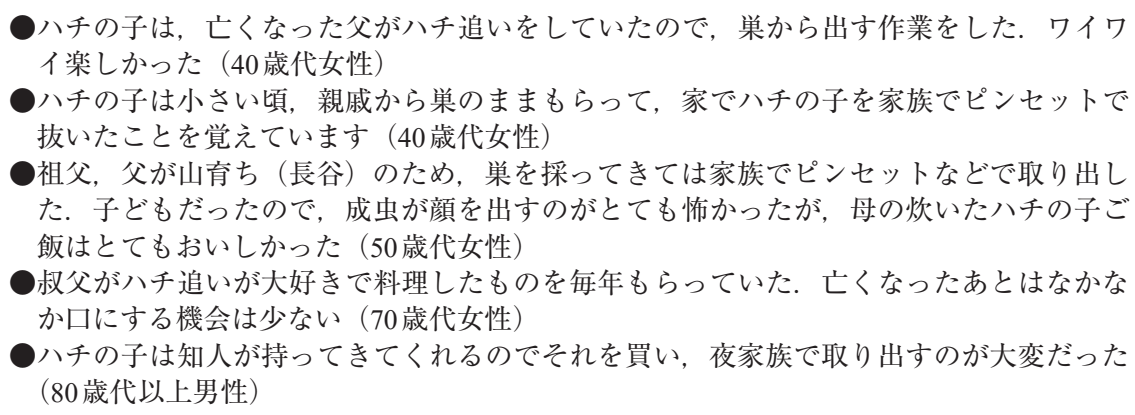 \\
\hline ハチの採集, 飼育の経験（39） & 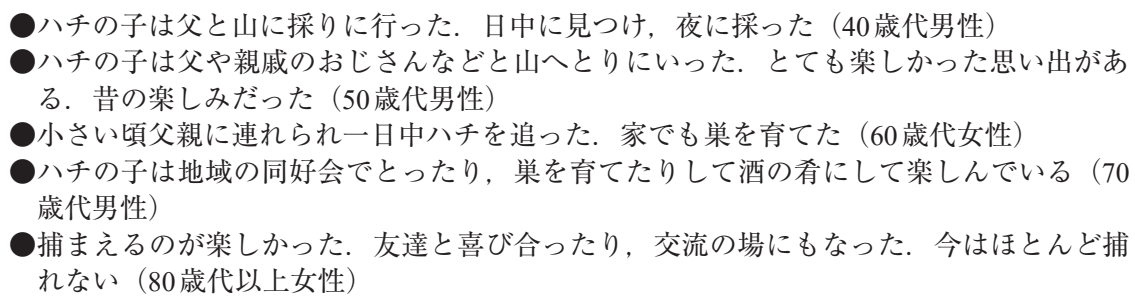 \\
\hline $\begin{array}{l}\text { 採集機会の減少, } \\
\text { 喫食頻度の低下 }\end{array}$ & 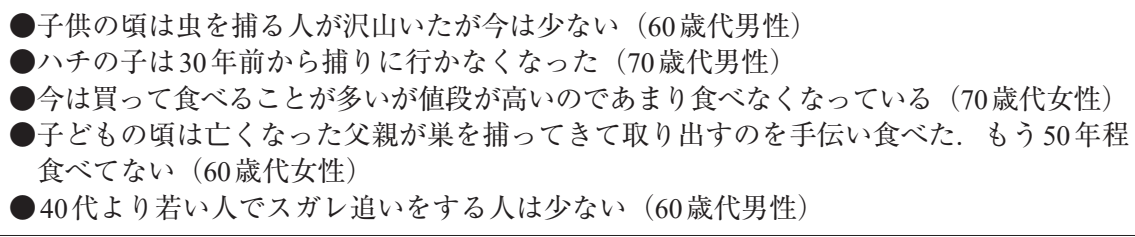 \\
\hline ハチの採集, 飼育の楽しさ（15） & 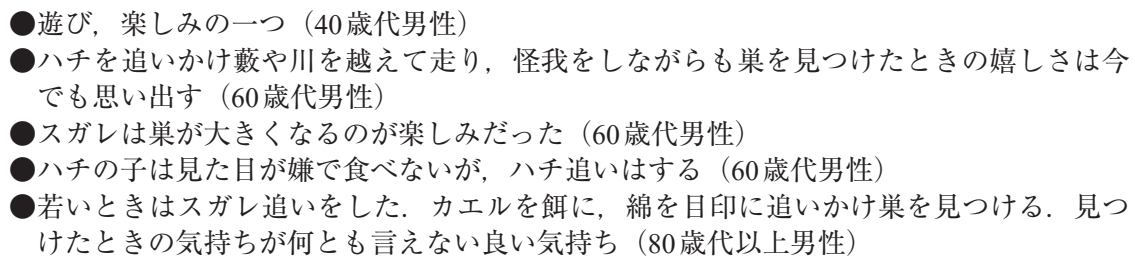 \\
\hline $\begin{array}{l}\text { ハチの子製品の価格, } \\
\text { 特別な日や場での提供（14） }\end{array}$ & 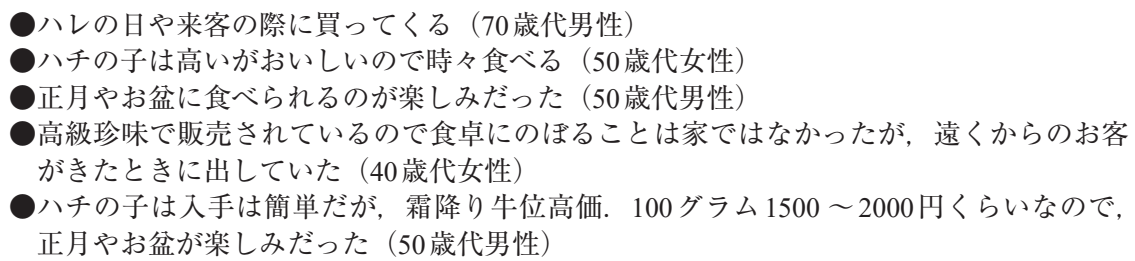 \\
\hline
\end{tabular}

注：「記入の事例」は語句や数值の表記形態を統一した上で, 原文の表現のまま使用. (アンケート結果より作成)

製造されたものか長野県内のほかの食品製造会社が製 造したものが使われていた。このうち県内の会社が製 造した製品の価格は，海外の原料を使っている直売所 Aの製品とほぼ同じ価格だった。

2）生息環境の変化と個体数の減少

アンケート結果より, 住民は, 調査対象地域ではイ ナゴの個体数が減少しており, そしてその原因は農薬 の使用や自然環境の変化であると考えていることがわ
かった。

伊那市（2000）によると，伊那市では戦後から現在 にかけて農家数と経営耕地面積は減少傾向, 耕作放棄 地面積は増加傾向にあることが報告されている。ま た，同文献では稲作に使われる農薬の一つである除草 剂は1960年代頃から日本各地で使われるようになっ たことも指摘されている，ただし，農地の減少や農薬 使用などがイナゴの個体数に直結しているとは簡単に 


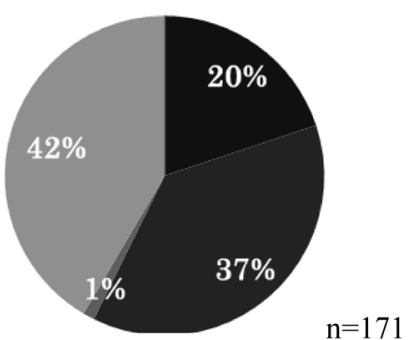

a. 20 年ほど前

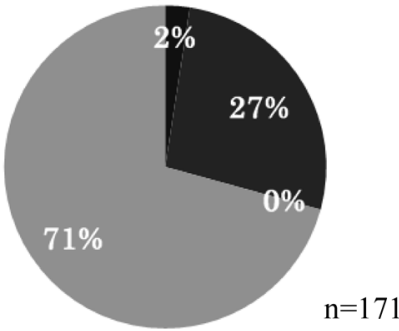

b. 現在

口自分や家族で捕まえる

友人等からもらう

ロ生きたものを店で購入する

調理されたものを店で購入する

図 7 ザザムシの入手方法

Fig. 7 Methods for obtaining zazamushi (stonefly larvae) (アンケート結果より作成)
はいえない.また，そもそも調査対象地域におけるイ ナゴの個体数の変化について詳しい調査はされていな いことから, どの程度個体数が減少しているのか正確 にはわからない. しかし，アンケートの自由記述や上 記の資料を合わせて考えると，農業手法や自然環境の 変化が調査対象地域のイナゴの個体数に一定程度影響 を与えていると考えられる。

そして, 個体数減少により昔のように消費者自ら捕 まえることが困難になり，また販売されている製品が 高価であることなどが影響した結果，住民のイナゴを 食べる頻度が減少したと考えられる。

なお, 近隣地域の一部の農家では現在も稲刚りの際 にイナゴを捕る様子が確認された（図 8).

2. 八チの子

1）流通構造の特徵と変化

八チの子の入手方法には，主に「調理済みの製品を 販売店で購入する」,「自分や家族で採集, 飼育する」, 「知人等からもらう」,「イベントの際に巣を購入する」 といった方法が挙げられる.

表 5 ザザムシ食に関する自由記述の例

Table 5 Examples of free comments on zazamushi consumption

\begin{tabular}{|c|c|}
\hline 確認された項目・観点（回答数） & 記入の事例（回答者の年代・性別） \\
\hline $\begin{array}{l}\text { ザザムシ製品の価格, } \\
\text { 特別な日や場での提供（8） }\end{array}$ & 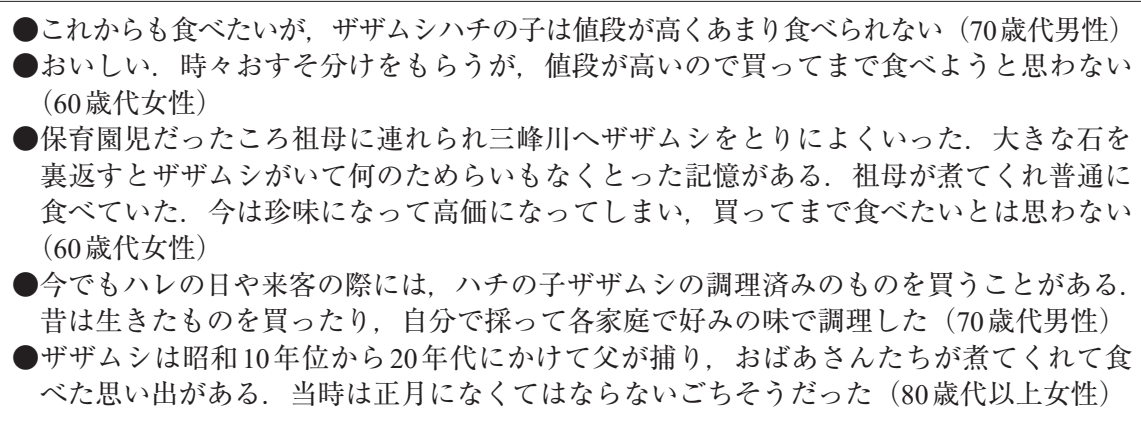 \\
\hline $\begin{array}{l}\text { 知人等からおすそ分けされた経験 } \\
\text { (5) }\end{array}$ & 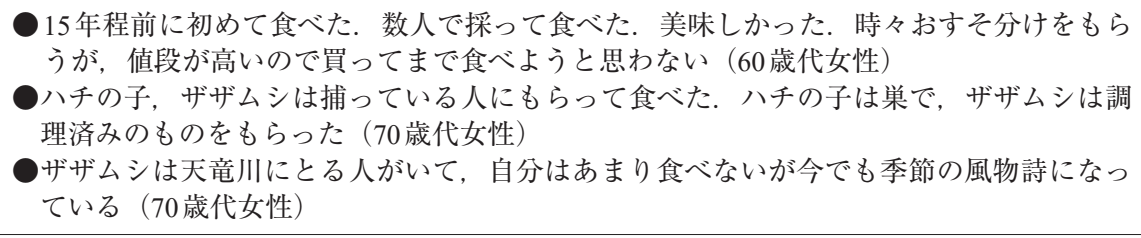 \\
\hline 見た目（4） & 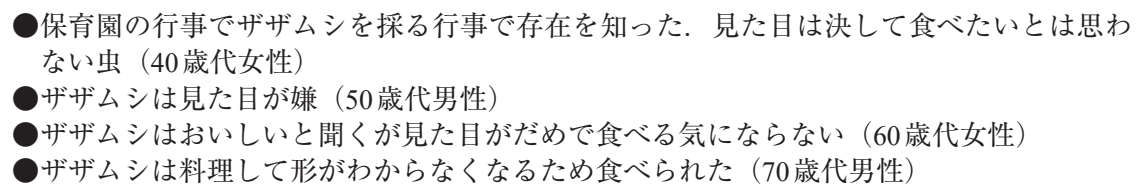 \\
\hline
\end{tabular}

注：「記入の事例」は語句や数值の表記形態を統一した上で, 原文の表現のまま使用.

（アンケート結果より作成） 


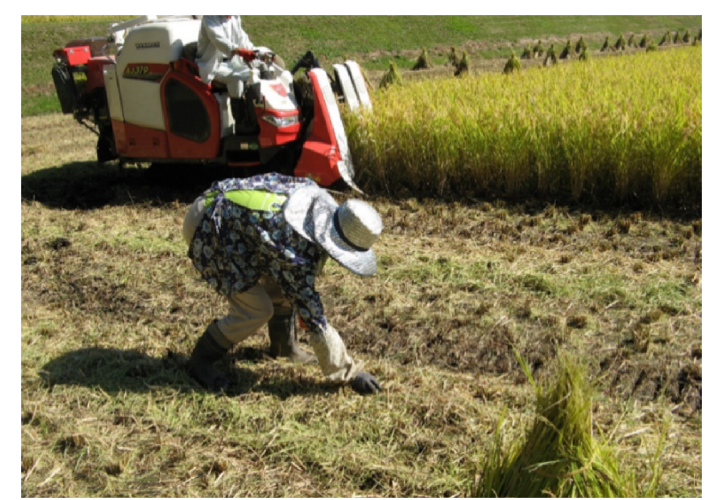

図 8 イナゴ採集の様子

Fig. 8 Oxyinae collection (2019年10月, 長野県原村で撮影)

このうち，製品を購入するのが現在最も一般的な入 手方法と考えられる。，八チの子製品を扱う市内直売所 Aでは 18 年ほど前からイナゴ同様にハチの子も海外 から輸入したものを製品の原料として利用しており， 現在は国内より海外の原料の利用比率が高い。ここま で述べてきた通りハチの子は入手の過程も重視されて きたが，アンケート結果より現在は量販店などで購入 したものを食べるという人が多いことから，原料供給 面で海外に依存する傾向もうかがえる.

一方, 製品購入より規模は小さいものの, 愛好会が 主催するイベントなどで八チの幼虫が入ったままの状 態で巣を販売，購入するという流通もみられる（図9). こうしたイベントでは，八チの巣を飼育した愛好者が 巣の重さを競い合った後, 巣の販売が扔こなわれる.

2018年に調査対象地域で開催されたものを含む二つ のイベントに打ける観察から，両イベントで巣の販売 がおこなわれており，どちらも巣 $1 \mathrm{~kg}$ 当たり 1 万円前 後で販売されていたことがわかった。購入者はイベン 卜開催地やその周辺地域の住民が多いが，中には遠方 から訪れた者や，八チの子を食べる習慣のない地域か ら訪れた者もみられた。他地域から訪れた購入者は, イベントの開催地域で以前生活していた者や八チの子 を食べる習慣のある地域に暮らしていた者が多かった． 購入理由としては「自分で味付けができる」（60歳代 男性）や「イベントに来た人や飼育を行っている人と 話しながら買うのが楽しい」(60歳代女性) という理 由を挙げる購入者が多かった。

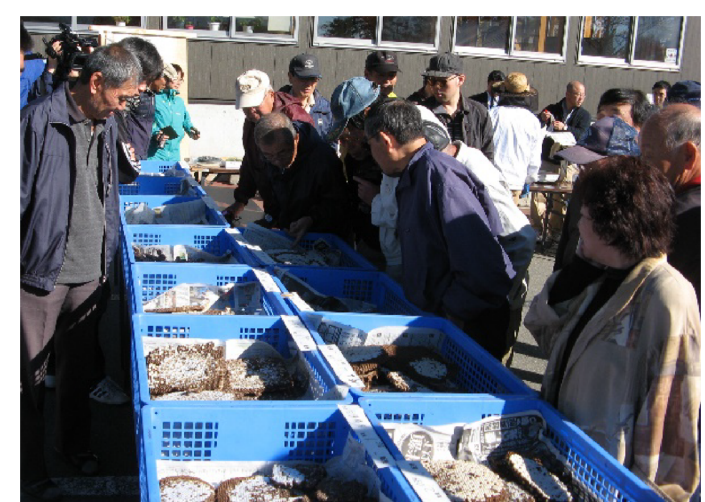

図9コンテスト会場でのハチの巣の流通

Fig. 9 Wasp nests sold at a festival (2018年 10 月，伊那市で撮影)

2）クロスズメバチの保護，増殖および「スガレ追 い」普及のための取組み

八チの子は食べる以外に「捕る」,「飼う」過程が趣 味として続けられてきた半面, 捕り過ぎや自然環境の 変化による資源量の減少という問題も経験している. 伊那市地蜂愛好会への聞取りによると,「昔に比べク ロスズメバチはかなり少ない」という。 アンケートで も「昔ほどみかけなくなった」(60歳代男性),「スガ レ追いをする人が初夏にたくさん捕るので秋にはあま り捕れない」(70歳代男性) という記述がみられた。

このような資源量の減少を受け，独自の保護活動を おこなっていた地域もある ${ }^{5}$ ，全国地蜂連合会への聞 取りによると，資源量の減少，あるいは八チ追いや飼 育を抗こなう者（担い手）の減少により食文化が衰退 する懸念から，1990年代前後に資源保護などを目的と した愛好会が八チの子を食べる習慣のある地域で設立 されるようになった，調查対象地域でも1997年, クロ スズメバチの保護，増殖および遊びの文化，食文化の 継承を目的とし「伊那市地蜂愛好会」が設立された。

調査対象地域では，八チの子食に関わる資源管理と して,「クロスズメバチの保護, 増殖」「スガレ追い の普及」，という二つの取組みがある，前者は食用昆 虫資源そのものの管理，後者は八チの子食に関わる人 の管理といえる。これらの活動はともに「伊那市地蜂 愛好会」によって扢こなわれている。

「クロスズメバチの保護，増殖」を目的とした活動 は，伊那市地蜂愛好会では「八チの越冬管理」と呼ば れる。これは，秋に巣から出た新女王バチと雄バチを 
交尾させ，その新女王バチを冬の間倉庫の中などで冬 眠させるという取組みである。冬眠したハチは翌年春 に愛好会の会員に配布し，会員は各々好きな場所に八 チを放つ。この取組みによって冬眠中のハチが自然界 より安全な環境で越冬でき, 翌年以降の個体数確保に 繋がる.

「スガレ追いの普及」を目的とした取組みとしては， 巣の飼育をおこなった者がその大きさ（重さ）を競う （図 10）コンテストを毎年開催している. そのほか, 新たに八チ追いや飼育をしようとする者向けに，それら の方法が記された冊子を作ったり，同じく興味をもっ た者向けの普及活動を年数回おこなったりしている.

こうした取組みがされている一方, 愛好会の会員数 は減少傾向にあり, 愛好会設立当初は 80 名ほどだっ た会員数は現在 40 名ほどになっている。もっとも， 愛好会に入らずハチ追いをしている人も多数おり，会 員数だけで判断することはできない。ただし，アン ケートでも「40代より若い人でスガレ追いをする人は 少ない」(60歳代男性),「昔の思い出」(70歳代男性) という記述がみられるほか, 愛好会の会員のほとんど が 60 歳代以上であることから, 担い手の減少や高齢 化は確実にみられる

3. ザザムシ

1）流通構造の特徵と変化

ザザムシは現在伊那谷地域のみで漁獲がおこなわれ

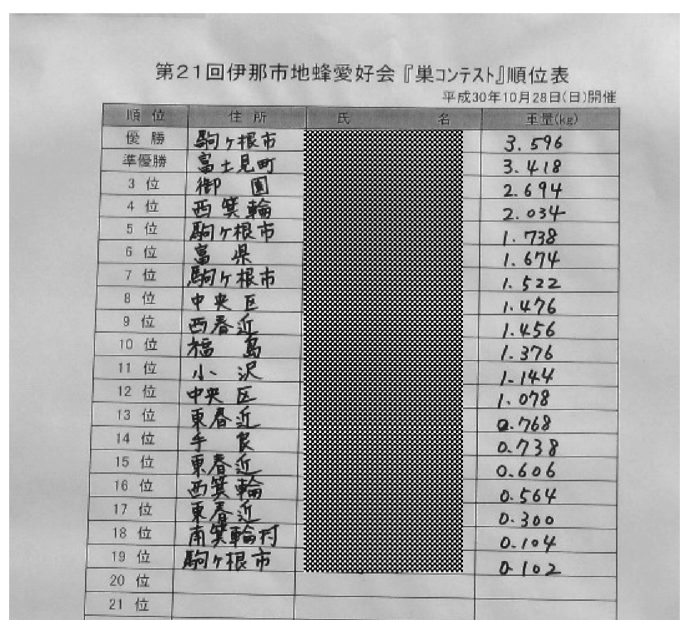

図10 地蜂の巣コンテストの結果

Fig. 10 Result of the Wasp Festival in Ina (2018年 10 月, 伊那市で撮影)
ている。漁獲されたザザムシはザザムシ製品を製造す る事業者のもとに持ち込まれる。このうち，伊那市内 の直売所 $\mathrm{A}$ では現在 $1 \mathrm{~kg}$ 当たり 6,000 円でザザムシを 買い入れている。こうしたザザムシ漁師と買取り業者 の関係は1940年代後半からみられる。また，捕れた ザザムシを全て業者に渡さず知人におすそ分けする漁 師も一定数存在していたことが, 前掲の図7で昔は 「友人等からもらった」という回答が多かったことか らも読み取れる。

このようにザザムシは調査対象地域のみで漁獲さ れ，その担い手も少ないことから商品として出回る量 は少なく，ほかの昆虫に比べ販売価格は高価である. 伊那市（2007）によると，2007年時点での昆虫製品 の $100 \mathrm{~g}$ 当たりの価格は八チの子が 1,700 円程なのに対 し，ザザムシは4,300円程とされている，また，筆者 が伊那市内の複数の販売店で観察した結果, 2018 年 10 月現在ザザムシはイナゴや八チの子，カイコのサナ ギに比べ $100 \mathrm{~g}$ 当たり千円〜数千円高い価格となって いた。 アンケート結果より現在昆虫を食べる住民の多 くは食用昆虫を購入しており，その価格について「高 級品」,「高いので頻繁には買えない」と答える人が多 いことから，ザザムシについては特に販売されている 製品の価格が消費者の入手の障壁となっていると考え られる。

2）漁業権の設定

現在, ザザムシの漁獲は伊那市内を流れる天竜川, 三峰川の天竜川漁業協同組合管内でおこなわれてい る. 同組合によって漁期が 12 月から 2 月末までと定め られており，組合が販売している鑑札（1シーズン 15,000円）（図 11）を購入することで漁が可能となる. なお，同組合ではザザムシの資源量維持，増加を目的 とした取組みや資源量の把握，ザザムシ漁普及を目的 とした定期的な活動はおこなっていない7).

図 12 はザザムシの漁獲量と鑑札購入者数の推移を 示している.これをみると，年によって漁獲量，鑑札 購入者数ともに変動が大きいもののどちらも減少傾向 にあることがわかる．特に鑑札購入者は減少が著しく， 現在は最も多かった時期の 4 分の 1 程度となっている. 調査をおこなった 2018 年シーズンの鑑札購入者数は 9 名だった。また，天竜川漁業協同組合への聞取りによ ると，漁をおこなう者の高齢化も進んでおり，現在は 


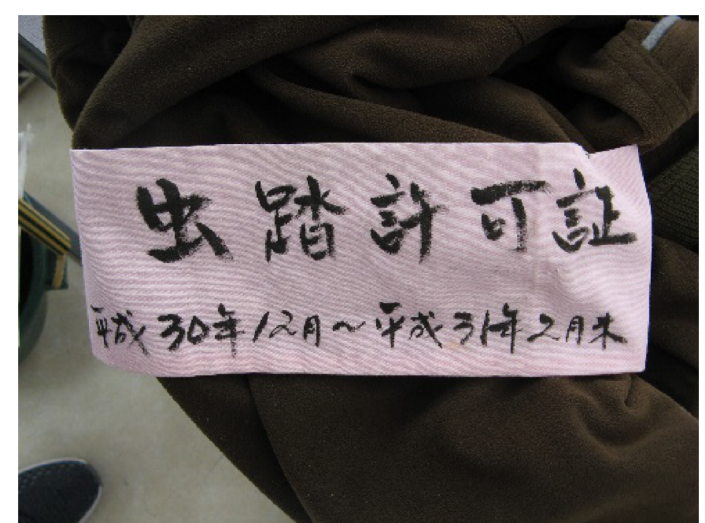

図11 ザザムシ漁の鑑札

Fig. 11 Zazamushi fishing license （2019年1月，伊那市で撮影）

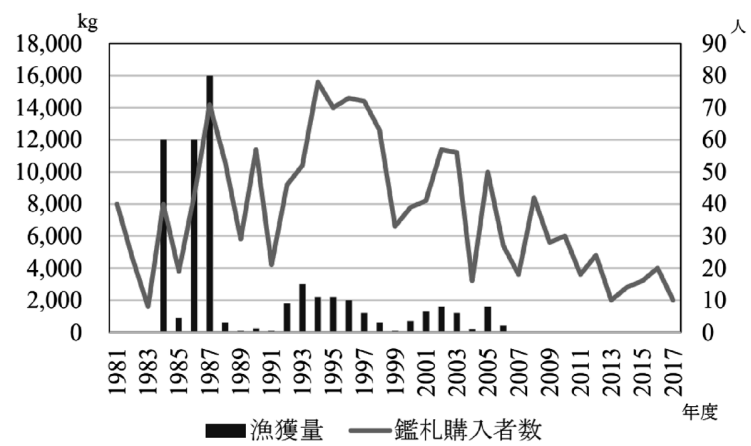

図 12 漁獲量と鑑札購入者数の推移

Fig. 12 Zamushi catch and number of licenses issued

注：漁獲量のデー夕は1984〜2006年のみ.

(天竜川漁業協同組合の記録を基に筆者作成)

70 歳代，80歳代の住民がほとんどだという．漁をお こなうには専用の道具や技術が必要であるほか, 冬の 川に入っての作業であるという漁の厳しさもあり，現 在漁をおこなう者は少ない。 また過去においても，イ ナゴのように老若男女問わず多くの住民が捕まえた, ということはなかった.

IIの2.で示したように，ザザムシは川の環境変化の 影響を強く受ける昆虫である，天竜川漁業協同組合へ の聞取りによると, 調査対象地域内を流れる三峰川の 一部では2009年に発生した山崩れで石灰質の砂が川 に流れ込み, ザザムシが生息する川底の石の隙間が埋 まったためザザムシが捕れなくなったという.

また，ザザムシ漁師によると，ザザムシ漁がおこな われる天竜川や三峰川の水質や水量, 川底の環境変化 により，漁期である 12 月から 2 月の資源量は毎年変化
する，特に，台風などの影響で大雨が降り川の水量が 一気に増えるということが頻繁にあった年は，川底の ザザムシが流れされ漁獲量が減るという。年により鑑 札購入者数に大きな変動がみられるのは，漁をおこな う技術のある住民が 1 年間川の様子を観察し，それに よってザザムシの資源量を予測，鑑札を購入するかど うか判断しているためであることがわかった.

4. カイコのサナギ

1）流通構造の特徵と変化

カイコのサナギを食べる文化は，その原料供給先と もいえる養虫業の衰勢との関連が強いと考えられる.

竹入（2005）によると, 伊那市を含む伊那谷地域で は17世紀後半から養虫がおこなわれるようになった。 初めは自家用だったものが次第に広がり 18 世紀後半の 高遠藩（現在の伊那市高遠町）の年貢項目には「養蚕 運上金」が登場する。19世紀になると商品化が進み, 伊那市を含む長野県各地から「為登糸」（地方から京 都へ送る糸）の出荷が増え，技術も向上した，明治維 新後生系は主要な輸出品となり, 伊那地方の $80 \%$ 近い 農家で養虫が抢こなわれた。昭和 10 年代（1930年代 後半〜1940年代前半), 食料増産の大号令により桑畑 は減少したものの, 農家は現金収入を求めカイコの飼 育は続けられた。しかし，その後人々の生活や働き方 が変化した結果, 1970 年代半ば以降養蚕農家は激減 した。

図 13 は現在の伊那市を構成する旧伊那市, 高遠町 および長谷村における養蚕農家数（戸数）の変化を示 したものである。これをみても1960年には3地区それ ぞれに養虫農家が存在していたものが，その後大きく 減少していることがわかる。2018年 12 月現在，伊那 市に養虫農家戸数はない.

原料供給先である養虫農家が地域内になくなったこ とから, 調査対象地域で現在食用とされているカイコ のサナギは全て地域外の原料を使用したものであると 考えられる. カイコのサナギ製品を製造，販売してい

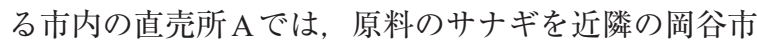
に現在もある製糸工場から仕入れ，利用している.

地域外の原料へ依存する傾向はイナゴ，八チの子で もみられたが, 地域外の原料のみによって現在の流通 構造が成り立っているのはカイコのサナギだけであ 


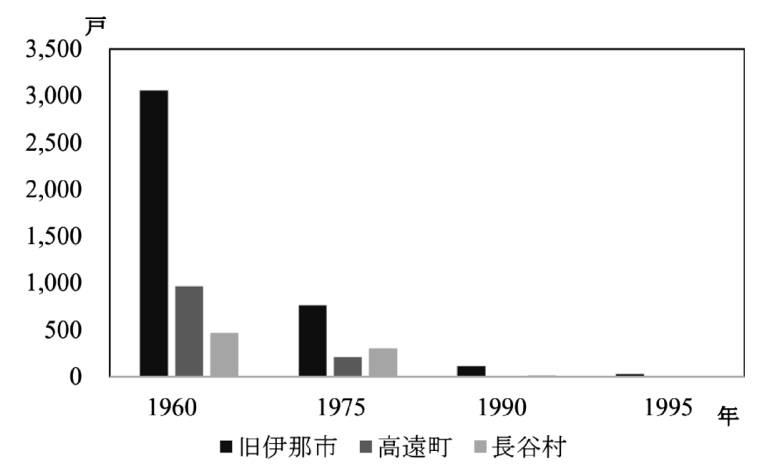

図 13 伊那市の養蚕農家数の変化

Fig. 13 Number of farmers raising silkwarms in Ina （中部地方建設局三峰川総合開発工事事務所（1998）を基に 筆者作成)

り, この点が伊那市における昆虫食の中でのカイコの サナギ食独自の特徴であるといえる。

\section{V 伊那市の昆虫食の多様性とその変化}

本章では，前章までの調查で得られた知見を基にし て, 長野県伊那市に打ける昆虫食に関して, 昆虫の採 集，流通，消費の穾態について，ここまで触れてきた 4 種類の昆虫全てを比較しつつ考察する.

図 14 は伊那市で現在食用とされている4種類の昆虫 について，それぞれの食文化を取り巻く社会・自然環 境や，食文化に関わる組織とその変化の様子を表した ものである。 また, 同じく 4 種類の昆虫の調査対象地 域内に扔ける住民の入手方法や流通構造等, 食行動が 成立する要件や構造とその変化の様子を図 15 にまと めた。

調查の結果から明らかになった第 1 点目として，昆 虫食を取り巻く環境や昆虫食に関わる人や組織は昆虫 の種類ごとに異なることを指摘できる.

イナゴは，かつては農地に行けば数多くみられ，捕 まえる際に特別な道具や技術を必要としないことから 多くの住民に食べられてきた昆虫であった，住民に とって最も馿染みのある食用昆虫で採集から調理, 消 費までを各家庭で抢こなうことが多かったことから， 主に家庭で受け継がれてきた食文化だといえる。

一方, 入手に専用の道具やある程度の技術が必要と される八チの子やザザムシは，捕ることができる住民 が家庭で消費するほか，販売店へ卸す，友人等におす
そ分けするという流通形態が多かった．各家庭で採集 し調理されてきたイナゴに比べ，採集や調理を（継続） する家庭と近所や友人等との関係性の中で成り立って きた食文化であるといえる。また，この2種類の昆虫 は，八チの子として食されるクロスズメバチの仲間は 伊那市地蜂愛好会に, ザザムシは天竜川漁業協同組合 によってそれぞれ女王バチの越冬管理や漁期の設定な ど, 個体数の維持や漁業権の設定といった資源管理が されている.

続いてカイコのサナギは, その原料供給源といえる 養虫業との関係が深く，養虫業が盛んだった時期には 養虫農家や製糸工場などでも食べられていた。

第2点目として, こうした食用昆虫の入手や流通, 消費事情は時代の流れにともなう社会・自然環境の変 化を受けその構造に変化が認められた。

イナゴは農業の機械化や農薬使用，人々の就業形態 の変化やそれにともない農地そのものが減少した影響 を受けその個体数が減少したと考えられる．また消費 者自身がイナゴを捕りに出かける機会も少なくなった 結果，イナゴを食べる習慣も衰退していった，食習慣 を維持した住民も，現在では調理済みの製品を量販店 などで購入することが多い、イナゴ食の維持におい て，かって原料の採集から消費までをおこなっていた 各家庭に代わり, 現在では食用のイナゴ製品を製造,

販売する量販店の役割が大きくなったといえる.

食用昆虫の採集に関わる住民损よび昆虫を食べる住 民の減少傾向はほかの昆虫でもみられる，また，現在 昆虫を食べる住民の多くは量販店などで購入したもの を食べる傾向も4種類の昆虫に共通している，たた し，八チの子のように採集行動そのものに楽しみが見 出されているものもあり，採集者の減少や昆虫の入手 における量販店への依存度合いには昆虫ごとに違いが みられる。

量販店などで販売される食用昆虫製品に使われてい る原料としての昆虫に注目すると，現在利用されてい るものの多くは調查対象地域外のものが多いことがわ かった．カイコのサナギは隣接地域，イナゴや八チの 子は長野県外や海外の昆虫が原料として使われてい る. なお，ザザムシはIVの3.で述べた通り現在伊那 地域でのみ漁獲されていることから, 地域内の原料の みが使われ続けている. 

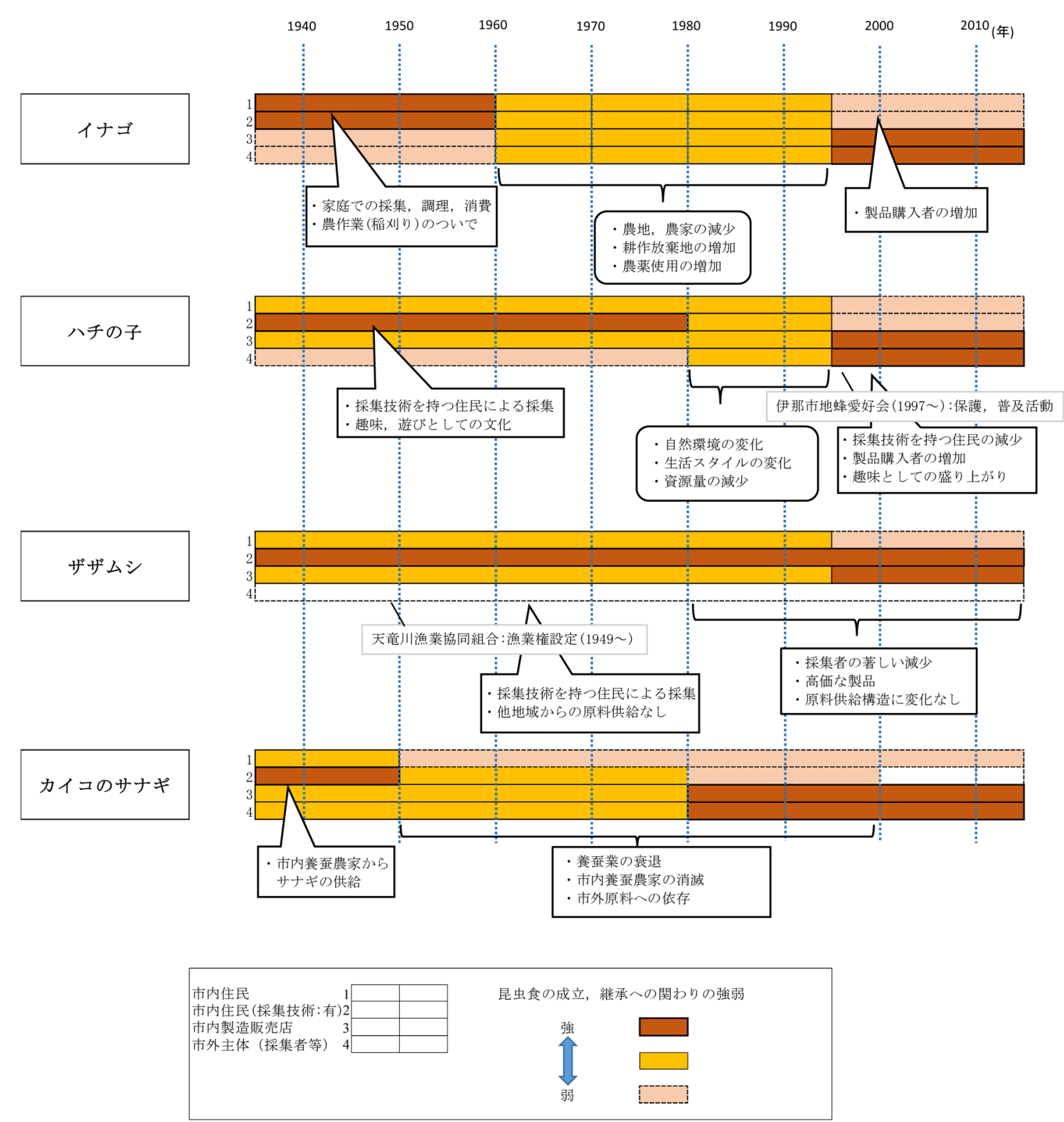

図 14 昆虫食を取り巻く環境, 昆虫食に関わる組織とその変化

Fig. 14 Environment and organizations supporting entomophagy in Ina （調査結果を基に筆者作成）

以上より，調査対象地域における昆虫食の流通構造 や食行動の成立要件は, 食用とされる昆虫の種類ごと にそれぞれ異なっており，またそれらは時代とともに 変化してきたことが確認できた。 このことから，それ ぞれ特徴が異なる複数の昆虫食が重なり合うことで, 「伊那市の昆虫食」が成り立っているといえる. 現在 「昆虫食」とひとくくりに説明される傾向があるが, 本稿での調査結果から, 伊那市の昆虫食文化の内部に みられる多様性を示すことができる。
また，地域の食文化を成立させる資源が地域内で採 集されるものだけでは足りていない実態，さらに消費 者自身が昆虫を採集する機会が少なくなった現在，昆 虫の入手先として製造販売店に依存する傾向が強く なっていることも明らかとなった。 このことは, 地域 の食文化である昆虫食の成立・継承の考察にあたり， 原料供給や食用昆虫製品の製造に関わる他地域, 組織 の存在や行動も念頭に置く必要があることを意味す る. 


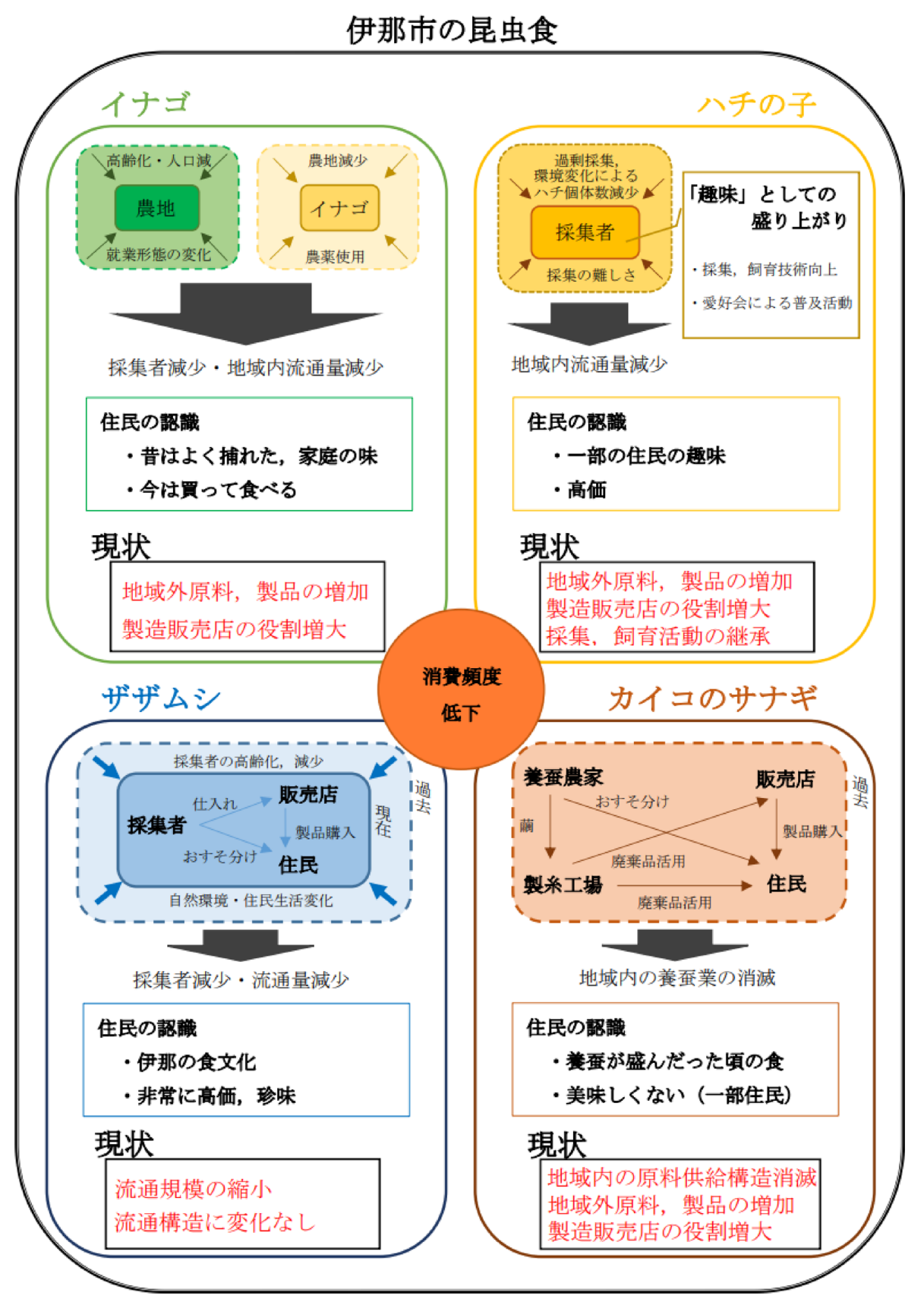

図 15 伊那市の昆虫食の実態

Fig. 15 Present status of entomophagy in Ina （調査結果を基に筆者作成）

伊那市の昆虫食における実態の一つとして, この地 域では現在でも半数以上の住民が昆虫を食する習慣が あることがわかった。 こうした需要の存在から，現在 市内で昆虫食製品の製造，販売をおこなっている直売 所や販売店，また販売のみをおこなっている量販店な どは今後も食用昆虫製品の製造や販売を続けていくと 考えられる，ただし，量販店などが扱う昆虫製品の原
料は現在, 隣接地域や長野県外, あるいは海外で確保 されたものが多い.このことは，原料供給地の自然環 境や人々の就業形態の変化, 流通環境の変化によって 昆虫製品の原料供給量も变動し, 結果として昆虫製品 の加工・流通が不安定になるリスクを示している.

また，現在は比較的維持されている伊那市の昆虫製 品への需要についても，年代が下がるごとに昆虫を食 
ベる習慣のある住民の割合が減っていることから，将 来的には今より需要量が減少することが考えられる. その際，需要が見込めない昆虫製品を販売店などが取 り扱い続けるかはわからない，住民が食用昆虫の入手 先として販売店に大きく依存している現状を鑑みると， 仮に今後需要量が大きく減少し, 販売店が昆虫製品の 販売を縮小あるいはおこなわなくなった場合, 伊那市 の昆虫食の維持・継承が困難になることが考えられる.

\section{VI おわりに}

本稿では, 長野県伊那市において現在食用とされて いる昆虫を把握し, 住民の昆虫食に対する認識や, それ ぞれの昆虫の採集および流通，消費状況，さらに生息 環境や採集環境の特徵や変化などの実態を明らかにす ることで, 当該地域の昆虫食の現状，今後の昆虫資源 利用の動向や持続可能性を考察することを目的とした.

その結果, 調査対象地域では住民の9割以上が何ら かの機会に昆虫を食べた経験があり，6割以上の住民 が現在も昆虫を食べる習慣があるということがわかっ た。ただし，昆虫を食べる習慣の有無には世代ごとに 差がみられた。60歳代以上の住民はその 7 ～割が現 在も昆虫を食べる習慣があるとわかった反面，20・30 歳代といった若い世代の住民は食習慣のない者が半数 以上であることが明らかとなった。

食用とされる昆虫はかつて 10 種類程度だったが, 現在ではイナゴ，ハチの子，ザザムシ，カイコのサナ ギの 4 種類である，昆虫の採集環境や流通構造，資源 管理の手法は昆虫ごとに異なっている.

伊那市内の昆虫食の現状として, 原料調達の面では 「地域外原料，製品の増加」，流通の面では「製造販売 店の役割増大」，消費の面では「契食頻度の低下」の 三つが挙げられる。このうち，「喫食頻度の低下」は 全ての昆虫にみられる一方，これ以外は 4 種類の昆虫 食全てに一様にあてはまっているわけではない.

自ら採集する者が減りながらもほかの昆虫と比べ日 常食としての色が強く, 比較的需要量も多いといえる イナゴは「地域外原料, 製品の増加」および「製造販 売店の役割増大」の二つの変化傾向がともに強い.

八チの子は，イナゴに似た変化傾向がみられる一 方，採集や飼育といった入手の過程に価值や楽しみが
見出されている点で微妙な違いがある．愛好会が組織 され，クロスズメバチの保護や採集，飼育文化の継承 もおこなわれている.

もともと伊那地域でのみ漁獲, 消費がおこなわれて いたザザムシは，漁師や消費者の減少により流通規模 に大きな縮小がみられる反面，流通構造自体の変化は 少ないといえる.

カイコのサナギは, 当該地域内に養虫農家がない現 在, 地域内での原料供給構造は消滅したといえ,「地 域外原料，製品の増加」，「製造販売店の役割増大」の 二つがあてはまる。また，ほかの昆虫では指摘されな かった味への不満があったことや，食べていると答え た者も少なかった点から「喫食頻度の低下」もほかの 昆虫に比べ強くみられる。

なお，量販店などで販売されている昆虫製品に使わ れている原料昆虫の多くは, 調査対象地域外のものが 使われており，供給が不安定になるリスクがあるとい える。

昆虫食の継承や変化状況の考察にあたり，当該地域 における若い世代の昆虫食の実態把握や，原料供給に 関わる人や地域の詳細な調査は本稿では追究できてい ない. 特に，八チの子やザザムシといった数少ない採 集者によって原料供給がおこなわれている昆虫につい て，採集者がどのような意識，目的で食用昆虫を採集 しているかは重要な研究課題である．また，アンケー 卜調査で課題として残った一部の食用昆虫における個 体数の減少が起きた時期やその要因の把握，さらには 事例地域以外の昆虫資源利用に関する研究蓄積が今後 の研究課題として挙げられる.

\section{謝 辞}

調査にあたり，伊那市教育委員会牧田豊様，立教大 学文学部野中健一教授, 天竜川漁業協同組合, 伊那市 地蜂愛好会, 全国地蜂連合会および付知ブラックビー クラブには調査実施に関わる有益な助言をいただきま した. 直売所 $\mathrm{A}$, 販売店 $\mathrm{B}$ ，および小沢地区，坂下地 区，手良地区沢岡の住民の皆様には聞取り，アンケー トへの回答にご協力をいただきました，金沢大学地域 創造学類環境共生コースの青木賢人准教授，林紀代美 准教授，およびゼミ学生からは多くのご教示をいただ きました。ご協力いただいた全ての皆様に，厚くお礼 
申し上げます。

本稿は, 2018 年度に金沢大学地域創造学類環境共生 コースへ提出した卒業論文を加筆修正して作成したも のである.この骨子は, 日本地球惑星科学連合2019年 大会（幕張メッセ）にて発表した.

\section{注}

1）国連食糧農業機関「昆虫の食料保障，暮らしそ して環境への貢献」を参照した. http://www.fao.org/ 3/i3264ja/i3264ja.pdf（最終閲覧日：2018年10月17日）

2）伊那市では「ザザムシ」はカワゲラの仲間の幼虫 のみを指し，「ざざ虫」が食用とされる水生昆虫 の幼虫全てを指すという表現の使い分けがされる ことがある（牧田 1999）が，本稿では食用の水生 昆虫全てを「ザザムシ」と表現する。

3）長野日報 2018年12月 2 日記事「伊那谷に冬の訪 れ『ザザムシ漁』解禁」.

4）平成 27 年国勢調査での伊那市の高齢化率は $30.1 \%$ である。アンケート調査対象地区の高齢化率は, 手良地区沢岡 35.5\%, 坂下地区 $42.8 \%$, 小沢地区 $33.4 \%$ である。

5）岐阜県加子母村（現在の岐阜県中津川市加子母） では，クロスズメバチの仲間の個体数維持を目的 に「加子母村ハイバチ資源確保に関する条例」と いう条例が1990年に定められ，資源保護がおこ なわれた（松浦2002）。なお，この条例は2005年 の加子母村の中津川市への編入合併にともない廃 止されている.

6）全国地蜂連合会への聞取りによると，他地域にお ける同様の愛好会の中には会員の減少および高齢 化が影響し運営できなくなったものも多く, 1990 年代には全国に 30 以上あった愛好会も現在は 10 以下に減少しているという。

7）ただし，2019年1月，天竜川漁業協同組合は長野 県上伊那地域振興局と共同で, 地元高校生に対す るザザムシ漁体験会を開催した。

\section{文 献}

伊那市 1981.『伊那市史一一自然編』伊那市.

伊那市 1999. 『伊那市ふるさと歳時記一—くらしと行 事』伊那市.

伊那市 2000. 『伊那市の農林業』伊那市.

伊那市 2007. 『伊那市ふるさと百科一あすの暮らし を育む文化事典』新葉社.

伊那市・川シンポジウム実行委員会 1996.『第9回 川シンポジウム報告集』伊那市.

太田猛彦・高橋剛一郎 2001。『溪流生態砂防学』東京 大学出版会.

竹入弘元 2005 .『ふるさと発見一一伊那市の歴史』草 舎出版.

田下昌志 - 丸山 潔 - 福本匡志 - 横山裕之 ·保科千 丈 2015.『信州人虫を食べる』信濃毎日新聞社.

中部地方建設局三峰川総合開発工事事務所 1998。『は じめての三峰川探検』建設省中部地方建設局.

辻 稜三 1993. 中国山地に打りトチノミ食とその 地域差について. 人文地理 45: 178-191.

手代木功基 2019. ナミビアにおける昆虫食文化と生 態環境. 砂漠研究 29: 45-51.

手良誌編集委員会 2012. 『手良誌』手良誌刊行委員会. 中村周作 2017. 佐賀県における伝統的魚介類食の地 域差. 人文地理 69: 485-499.

長野県 2019.『信州伊那谷のおいしい昆虫』長野県上 伊那地域振興局.

野中健一 1989. 中部地方におけるクロスズメバチ食 慣行とその地域差. 人文地理 41: 276-290.

野中健一 2005。『民族昆虫学一一昆虫食の自然誌』東 京大学出版会.

野中健一 2008.『昆虫食先進国ニッポン』亜紀書房.

藤岡悠一郎 2006. ナミビア北部に暮らすオヴァンボ 農牧民の昆虫食にみられる近年の変容. エコソフィ ア 18: 95-109.

牧田 豊 1999.『伊那の冬の風物詩——゙ザムシ』天 竜川上流工事事務所調査課.

升原且顕 2005. 広島県における食慣行の伝承に関す る考察——和町の「ワニ」料理を中心に，立命館 地理学 17: 101-115.

松浦 誠 2002.『スズメバチを食べる——昆虫食を訪 ねて』北海道大学図書刊行会。

水野 壮 2016. 現代の昆虫食の価值—ヨーロッパ および日本を事例に. 国際交流研究 18: 159-178.

三橋 淳 1997.『虫を食べる人びと』平凡社.

三宅恒方 1919. 食用乃薬用昆虫二関スル調査. 農事 試験場特別報告 31: 1-203.

Nakanishi, R. 2009. Development of rice-based integrated multiproduct farming in the Saku Basin in Nagano Prefecture from the 1880s to the 1930s. Geographical Review of Japan 82B: 14-30.

〈著者略歴〉

小林 直樹（こばやし なおき）

1996年長野県生まれ。金沢大学大学院生.人間社会環境研究科地域創造学専攻所属. 